ks. Janusz Królikowski

Uniwersytet Papieski Jana Pawła II w Krakowie

\title{
Życie zakonne między konsekracją, komunią i posłaniem
}

\begin{abstract}
Śnię o nowym Franciszku z Asyżu lub o nowym Ignacym Loyoli, który przyszedłby pokazać nam nowy styl życia chrześcijańskiego (bardziej zlączonego ze światem, a równocześnie bardziej od niego oddzielonego), jakiego potrzebujemy.
\end{abstract}

Pierre Teilhard de Chardin SJ

\section{Aktualność życia konsekrowanego}

Od zakończenia II Soboru Watykańskiego, opatrznościowego wydarzenia w dziejach Kościoła w naszym wieku, minęło pół wieku i jesteśmy ciągle na początku jego recepcji, tak w życiu Kościoła, jak w teologii. Ten niezbyt dlugi okres posiada jednak wszystkie cechy charakterystyczne osobnej epoki historycznej w Kościele, zarówno z punktu widzenia nowego rozmachu duszpasterskiego i duchowego, jaki zrodził się w tym czasie na wszystkich kontynentach, jak również z punktu widzenia pilnej potrzeby zmierzenia się z nowymi „wyzwaniami” (by powołać się na jedno z pojęć częściej spotykanych w najnowszych dokumentach doktrynalno-duszpasterskich Kościoła), które wyrażają przekształcenia burzliwie weryfikujące się w przejściu 
między czasami nowożytnymi i postnowożytnymi, którego jesteśmy świadkami oraz bezpośrednimi uczestnikami i twórcami.

Ta sama ogólna cecha charakterystyczna, która jest odczuwana w całym Kościele, odzwierciedla się niezwykle wyraźnie w najnowszych dziejach życia zakonnego, którego ramy wyznaczają dokumenty soborowe: konstytucja dogmatyczna Lumen gentium (rozdział szósty) i dekret Perfectae caritatis oraz adhortacja posynodalna papieża Jana Pawła II Vita consecrata (25 marca 1996), będąca owocem specjalnego synodu poświęconego życiu konsekrowanemu (2-29.10.1994), mająca na celu dokonanie pogłębionej recepcji nauczania soborowego ${ }^{1}$. Nie ulega najmniejszej wątpliwości, że ten niezbyt długi okres będzie za jakiś czas uznany za osobny i szczególny etap w dziejach życia konsekrowanego w Kościele. Wystarczy wziąć pod uwage wielki rozwój teologiczny, duchowy i duszpasterski, który nastąpił w jego ramach, oraz zauważyć, z jaką niecierpliwością i odwagą szukano w tym czasie nowych form życia konsekrowanego, które byłyby w stanie pełniej odpowiedzieć na najnowsze i najbardziej wymagające znaki czasu. Przy tym wszystkim, co stanowi niewątpliwie wymiar pozytywny okresu posoborowego w ramach życia zakonnego, należy także pamiętać i o tym, że posiada on wszystkie cechy charakterystyczne ,kryzysu” - niektórzy dodają przymiotnik ,głębokiego" - dotyczącego zarówno tożsamości życia konsekrowanego, jak i adekwatnie interpretowanego jego posłania w Kościele i świecie ${ }^{2}$.

W tym kontekście staje się jasne, że Kościól zawsze potrzebował i stale potrzebuje zatrzymywania się nad zagadnieniem życia zakonnego, by móc, w modlitwie i refleksji, albo odnaleźć minione, może trochę zagubione lub zaciemnione, chociaż zawsze wartościowe, drogi swojego życia i rozwoju, albo odkryć możliwe nowości ukryte jeszcze w głębiach tajemnicy Ducha Świętego. To zatrzymanie się nad życiem konsekrowanym w Kościele wyraziło się w szczególny sposób przez ogłoszony przez papieża Franciszka Rok Życia Konsekrowanego. Wyznaczone przez papieża cele na ten rok to: a), spojrzeć w przeszłość z wdzięcznością”, b) „,przeżywać teraźniejszość z pasją”,

\footnotetext{
Por. P. Liszka, Charyzmat życia zakonnego, Wrocław-Warszawa 2002.

2 Wiele ważnych uwag na temat współczesnej sytuacji życia zakonnego można znaleźć w: Przetrwanie czy proroctwo? Listy Thomasa Mertona i Jeana Leclercqa, tł. A. Wojtasik, Kraków 2004; E. Bianchi, Non siamo migliori. La vita religiosa nella chiesa, tra gli uomini, Magnano 2002.
} 
c) ,przyjąć przyszłość z nadzieją"3. Warto zauważyć, że propozycja papieża Franciszka sytuuje się w bezpośredniej łączności z nauczaniem św. Jana Pawła II. Papież Franciszek pisze:

Po wysłuchaniu opinii Kongregacji ds. Instytutów Życia Konsekrowanego i Stowarzyszeń Życia Apostolskiego wskazałem jako cele tego roku te same, jakie święty Jan Paweł II zaproponował Kościołowi na początku trzeciego tysiąclecia, podejmując w pewien sposób to, co wskazał już w adhortacji posynodalnej Vita consecrata: „Powinniście nie tylko wspominać i opowiadać swoją chwalebną przeszłość, ale także budować nową, wielką historię! Wpatrujcie się w przyszłość, ku której kieruje was Duch, aby znów dokonać z wami wielkich dziel"4.

Uzasadnione jest zatem, aby jeszcze raz powrócić do adhortacji apostolskiej Vita consecrata papieża Jana Pawła II, szukając w niej inspiracji dla pogłębionego rozumienia życia konsekrowanego w Kościele oraz adekwatnego odczytywania jego misji pośród ludzi. Adhortacja Vita consecrata jest w pewnym sensie „,kodyfikacją” teologiczną i profetyczną głosów ojców synodalnych, przybyłych z całego świata do Rzymu w październiku 1994 roku, mającą na względzie przyszłość życia konsekrowanego w Kościele i jego znaczenie dla świata oraz jego nowe dynamiczne podjęcie z wiarą i odwagą, którego oczekuje cały Kościól ${ }^{5}$. Papież Jan Paweł II tak wyrazil to oczekiwanie:

Ufając, że dzieci Kościoła, a zwłaszcza osoby konsekrowane, zechcą przyjąć życzliwie także tę adhortację, pragnę wyrazić życzenie, aby dalsza refleksja pozwoliła na coraz głębsze zrozumienie wielkiego daru życia konsekrowanego w potrójnym wymiarze konsekracji, komunii i misji oraz by skłoniła osoby konsekrowane, trwające w pełnej harmonii z Kościołem i jego Magisterium, do szukania nowych odpowiedzi o charakterze duchowym i apostolskim na pojawiające się wyzwania ${ }^{6}$.

3 Franciszek, List apostolski do zakonnic i zakonników na rozpoczęcie Roku Życia Konsekrowanego Świadkowie radości (21.11.2014), nr 1-3 [dalej: ŚR].

4 ŚR 10.

5 Por. J. M. Kallidukil, The canonical significance of the Synod of Bishops of 1994 on consecrated life. From the Lineamenta to the „Vita consecrata”, Frankfurt am Main 2003. 


\section{Tożsamość życia konsekrowanego}

U podstaw każdego kryzysu znajduje się utrata tożsamości osobowo-duchowej, która może zweryfikować się w przypadku pojedynczej osoby, a także grupy czy nawet jakiejś społeczności ludzkiej. Ma to także miejsce w życiu duchowym, chrześcijańskim, eklezjalnym... Życie konsekrowane nie stanowi pod tym względem wyjątku. U podstaw kryzysu lub kryzysów życia konsekrowanego ostatnich dziesięcioleci, jak uczciwie odnotowuje się w analizach tej dziedziny życia eklezjalnego, znajduje się kompleks zjawisk i charakterystycznych cech, które dotyczą tożsamości teologiczno-duchowej osoby konsekrowanej. W rozmowach z zakonnikami i zakonnicami, często nawet po wielu latach życia zakonnego, można usłyszeć stwierdzenia w rodzaju: ,właściwie to ja nie wiem, kim jestem; nie jestem w stanie odnaleźć się w tym, co robię; potrzebuję czasu, by odnaleźć moją tożsamość...”. W niektórych przypadkach sytuacja staje się rzeczywiście dramatyczna i niepokojąca, domagając się konkretnego i otwartego postawienia pewnych zagadnień dotyczących samej istoty życia konsekrowanego. Trzeba przyznać, że w okresie posoborowym oficjalne nauczanie Kościoła i teologia bardzo owocnie zajmuje się tym zagadnieniem ${ }^{7}$.

Chciałbym wskazać w tym miejscu tylko jeden aspekt - myślę, że jeden z pierwszorzędnych - kryzysu tożsamości, przez jaki przechodzi życie konsekrowane, a także inne obszary życia eklezjalnego. Najgłębsze kryzysy w życiu Kościoła rodzą się głównie na podłożu teologicznym. Dzieje się to wtedy, gdy zostają zaciemnione autentyzm i specyfika wiary chrześcijańskiej w odniesieniu do jej treści i gdy mało uwagi poświęca się podstawowym prawdom wiary, jakby „to, w co wierzymy”, było czymś względnym i obojętnym. Niejednokrotnie zapomina się, że wiara opiera się na Prawdzie, i skonkretyzowana w odniesieniu do człowieka treść tej prawdy jest nieomylnym wyznacznikiem tożsamości chrześcijańskiej. Wskazano już wielokrotnie, że w naszych czasach w szczególnym kryzysie znajduje się podstawowy dogmat wiary chrześcijańskiej, to znaczy dogmat Trójcy Świętej, a przecież to na nim opiera się cała budowla

7 Por. S. Tassotti, La consacrazione religiosa. Dal Concilio Vaticano II all'esortazione apostolica „Vita consecrata”, Roma 2003. 
chrześcijańska i on najwłaściwiej wyznacza i kształtuje duchowe wymiary życia wiary ${ }^{8}$.

Karl Rahner już kilkadziesiąt lat temu postawił następującą diagnozę, niepokojącą z dogmatycznego i duchowego punktu widzenia:

Chrześcijanie, mimo ich poprawnego wyznania Trójcy Świętej, [są] jakby tylko ,monoteistami” w praktyce ich życia religijnego. Można by więc zaryzykować stwierdzenie, że jeśli musiałoby się zawiesić, jako fałszywe, nauczanie o Trójcy Świętej, to mimo takiej interwencji duża część literatury religijnej mogłaby pozostać prawie niezmieniona. Nie można temu nawet przeciwstawić się, mówiąc, że nauczanie о wcieleniu jest teologicznie i religijnie tak centralne dla chrześcijan, że pozostając na tym gruncie Trójca byłaby zawsze i wszędzie nierozdzielnie „obecna” w ich życiu religijnym?

Ta diagnoza rzeczywiście często znajduje oparcie w konkretnej rzeczywistości chrześcijańskiej. Z drugiej strony - i praktyka to potwierdza - wystarczy sam powrót do integralnej prawdy chrześcijańskiej, by odnaleźć się na gruncie chrześcijańskim i na nowo, w konkretnej codzienności, zacząć przeżywać treści należące do credo. W tym sensie zrozumiałe jest poszukiwanie trynitarnego pogłębienia tożsamości życia konsekrowanego w pierwszym rozdziale adhortacji Vita consecrata papieża Jana Pawła II, zatytułowanym w sposób bardzo znaczący: „Confessio Trinitatis. Chrystologiczno-trynitarne źródła życia konsekrowanego". Rozdział ten nie jest tylko pobożnościową medytacją teologiczną, mającą na celu wprowadzenie do ważniejszych zagadnień, ale jest pierwszorzędną częścią papieskiego dokumentu, dającą oparcie dla całej reszty; rozdział ten stanowi ,,serce” adhortacji papieskiej. Kto nie dokona głębokiej i integralnej recepcji rozdziału pierwszego, nie będzie w stanie zrozumieć i wprowadzić w życie rozdziału drugiego i trzeciego.

Życie konsekrowane posiada przede wszystkim genezę ewangeliczno-chrystologiczną:

8 Por. J. Królikowski, Tajemnica Trójjedynego. Studia z teologii trynitarnej, Kraków 2015, s. 203-217.

9 K. Rahner, Der dreifaltige Gott als transcendenter Urgrund der Heilsgeschichte, w: ,,Mysterium Salutis". Grundriss heilsgeschichtlicher Dogmatik, t. 2: Die Heilsgeschichte vor Christus, red. J. Feiner, M. Löhrer, Einsiedeln-Zürich-Köln 1978³, s. 319. 
Ewangelicznych podstaw życia chrześcijańskiego należy szukać w szczególnej relacji, jaką Jezus nawiązał w czasie swego ziemskiego życia z niektórymi spośród swoich uczniów, wzywając ich, by nie tylko przyjęli królestwo Boże we własnym życiu, ale także by oddali swoje istnienie w służbę tej sprawy, porzucając wszystko i naśladując wiernie Jego sposób życia ${ }^{10}$.

Ta geneza rozwija się z kolei w wymiarach szerszych, w pewnym sensie uniwersalizujących z teologicznego punktu widzenia:

Człowiek jest zdolny do takiej egzystencji „,na wzór Chrystusa”, do jakiej zostało wezwanych w ciągu dziejów bardzo wielu ochrzczonych jedynie na mocy specjalnego powołania i szczególnego daru Ducha Świętego. Konsekracja chrzcielna prowadzi tu bowiem do radykalnej odpowiedzi, polegającej na nasłladowaniu Chrystusa poprzez przyjęcie rad ewangelicznych, wśród których pierwszą i najistotniejszą jest slubowana czystość dla królestwa niebieskiego. Tak więc to szczególne „naśladowanie Chrystusa”, u którego początków zawsze jest inicjatywa Ojca, ma zasadniczy wymiar chrystologiczny i pneumatologiczny, dzięki czemu wyraża w sposób niezwykle żywy trynitarny charakter chrześcijańskiego życia, uprzedzając niejako jego realizację eschatologiczną, ku której zmierza cały Kościół11.

Aby zilustrować to dynamiczne przecinanie się wymiarów teologicznych życia konsekrowanego, adhortacja Vita consecrata zwraca uwagę na tajemnicę przemienienia Chrystusa, które stało się miejscem jednej z nowotestamentowych teofanii trynitarnych i wyznaczyło decydującą chwilę w posłaniu zbawczym Jezusa Chrystusa. Dla uczniów stało się ono punktem odniesienia w późniejszej refleksji nad misterium paschalnym i nad ich posłaniem w świecie.

Ojciec, w tajemnicy przemienienia, ukazuje Chrystusa jako osobowe centrum życia chrześcijańskiego, a w konsekwencji także życia konsekrowanego w profesji rad ewangelicznych, które ,,bardziej niż wyrzeczeniem, są [...] przede wszystkim specyficzną formą przyjęcia tajemnicy Chrystusa, przeżywaną w Kościele"12. To przyjęcie

\footnotetext{
VC 14.

VC 14.

VC 16.
} 
wyznacza w jednoznaczny sposób zadania, jakie z niego wynikają i jakie je potwierdzają:

Zadanie powierzone życiu konsekrowanemu polega na ukazywaniu, że Wcielony Syn Boży jest eschatologicznym celem, ku któremu wszystko zmierza, blaskiem, przy którym blednie wszelkie inne światło, nieskończonym pięknem, które samo zdolne jest zaspokoić wszystkie pragnienia ludzkiego serca ${ }^{13}$.

Innymi słowy, osoba konsekrowana przyjmuje Chrystusa jako sens swojego życia i ,naśladuje Go całym sercem”, a także ,,przeżywa i wyraża swoją konsekrację przez poddanie Chrystusowi całej egzystencji, które «upodabnia» do Niego, i przez totalny wysiłek, który zapowiada - na miarę osiaggalną w doczesności i zgodnie z różnymi charyzmatami - eschatologiczną doskonałość”, a w ten sposób odtwarza w sobie ,ttę formę życia, jaką obrał sobie Syn Boży przyszedłszy na ziemię"14.

Ta geneza chrystologiczna życia konsekrowanego nie jest zamknięta w sobie, ale rozwija się teologicznie w kierunku trynitarnym, by w sposób możliwie najpełniejszy stać się Confessio Trinitatis. Pierwsza ,,prawda" tego wyznania polega na uznaniu absolutnego pierwszeństwa Boga Ojca i Jego inicjatywy w misterium powołania do życia konsekrowanego - „A Patre ad Patrem”15. Druga ,prawda” wyraża fakt, że życie konsekrowane jest ze swej istoty „,pójściem za Chrystusem” (,,per Filium”), aby upodobnić się do Niego i uczestniczyć w Jego zbawczym posłaniu: „To porzucenie wszystkiego i pójście za Chrystusem (por. Łk 18, 28) stanowi właściwy program wszystkich ludzi powołanych i na wszystkie czasy" ${ }^{16}$. Trzecia ,prawda” stwierdza, że Duch Święty jest pierwszym Działającym w osobie konsekrowanej (jak zresztą w każdym chrześcijaninie) oraz skutecznie upodabnia ją do Chrystusa i tylko On jest jedyną mocą życia osoby konsekrowanej (,,in Spiritu”):

To Duch budzi pragnienie pełnej odpowiedzi; to On kieruje wzrostem tego pragnienia, skłania do udzielenia pozytywnej odpowiedzi,
VC 16.
VC 16.
Por. VC 17.

16 VC 18. 
a później pomaga w jej wiernej realizacji; to On formuje dusze powołanych, upodabnia ich do Chrystusa czystego, ubogiego i posłusznego oraz przynagla do podjęcia Jego misji, oni zaś, idąc pod przewodnictwem Ducha drogą nieustannego oczyszczenia, stają się stopniowo osobami uksztaltowanymi na wzór Chrystusa - historyczną kontynuacją szczególnej obecności zmartwychwstałego Pana ${ }^{17}$.

Perspektywa trynitarna nadaje następnie szczególny teologiczny wymiar radom ewangelicznym, które - widziane w niej jako dar trynitarny ${ }^{18}$ i wprowadzane w życie - mogą rzeczywiście stać się w konkretnym człowieku odbiciem wewnętrznego życia Boga:

Czystość [...] jest odblaskiem nieskończonej miłości łączącej trzy Boskie Osoby w tajemniczej głębi życia trynitarnego. [...] Ubóstwo [...] wyraża calkowity dar z siebie, jaki składają sobie nawzajem trzy Osoby Boskie. [...] Posłuszeństwo [...] objawia wyzwalające piękno uległości synowskiej, a nie niewolniczej, wzbogaconej poczuciem odpowiedzialności i przenikniętej wzajemnym zaufaniem: to zaufanie jest doczesnym odblaskiem harmonii miłości, właściwej trzem Boskim Osobom ${ }^{19}$.

Rady ewangeliczne ukazują więc w pełni swój blask trynitarny, gdy są przeżywane w pełnym miłości odniesieniu do Osób Boskich w Ich konkretności:

Życie konsekrowane jest zatem powołane, aby nieustannie wzbogacać dar rad ewangelicznych miłością coraz prawdziwszą i mocniejszą, przeżywaną w wymiarze trynitarnym: miłością do Chrystusa, która wzywa do zażyłej przyjaźni z Nim; miłością do Ducha Świętego, która usposabia duszę na przyjęcie Jego natchnień; miłością do Ojca - najgłębszego źródła i najwyższego celu życia konsekrowanego. W ten sposób staje się ono wyznaniem i znakiem Trójcy Świętej, której tajemnica zostaje ukazana Kościołowi jako wzór i źródło wszelkich form chrześcijańskiego życia ${ }^{20}$.

\footnotetext{
VC 19.

Por. VC 20.

VC 21.

VC 21.
} 
Przechodząc przez taką ,,polaryzację” trynitarną, życie konsekrowane ukazuje się w swojej oryginalnej i specyficznej tożsamości teologicznej, która daje ,wystarczające racje” do konkretnej aktualizacji genezy chrystologicznej każdej osoby konsekrowanej, to znaczy do kontemplacji i naśladowania Chrystusa ${ }^{21}$; do zjednoczenia się z Jego Paschą ${ }^{22}$; do świadczenia o Nim w świecie ${ }^{23}$; do zaakceptowania i dowartościowania eschatologicznego wymiaru życia codziennego ${ }^{24}$; do zaangażowanego i czujnego oczekiwania ukazania się Chrystusa chwalebnego na końcu czasów ${ }^{25}$, a w końcu, do przyjęcia Dziewicy Maryi jako wzoru konsekracji i pójścia za Chrystusem² ${ }^{26}$.

„Zakorzenienie” życia konsekrowanego w tajemnicy Trójcy Świętej dostarcza także racji teologicznych, by wejść głębiej w Kościół i poświęcić się dla niego. Życie konsekrowane przyjmuje w ten sposób szczególną rolę - „obiektywne pierwszeństwo” - jaką miało i ma nieustannie w wyznaczaniu modelu świętości Kościoła:

Właśnie dlatego najobficiej objawiają się w nim [życiu konsekrowanym - J. K.] ewangeliczne dobra i najpełniej urzeczywistnia cel Kościoła, to znaczy uświęcenie ludzkości. Życie konsekrowane zapowiada i w pewien sposób uprzedza nadejście przyszłej epoki, kiedy to nastąpi pełnia królestwa niebieskiego, które już teraz jest obecne w zalążku i tajemnicy, i kiedy po zmartwychwstaniu ludzie nie będą się już żenić ani wychodzić za mąż, lecz będą niczym aniołowie Boży (por. Mt 22, 30) 27 .

To zakorzenienie życia konsekrowanego w tajemnicy Trójcy Świętej ukazuje, że w Kościele jest możliwe i konieczne przejście od świętości udzielanej przez sakramenty do świętości życia codziennego, jaka aktualizuje się konkretnie w błogosławieństwach ewangelicznych:

Życie konsekrowane spełnia szczególne zadanie: podtrzymuje w ochrzczonych świadomość podstawowych wartości Ewangelii,
Por. VC 23.
Por. VC 24.
Por. VC 25.
Por. VC 26.
Por. VC 27.
Por. VC 28.

$22 \quad 27 \quad$ VC 32. 
dając ,wspaniałe i zaszczytne świadectwo temu, iż świat nie może się przemienić ani ofiarować się Bogu bez ducha ewangelicznych Błogosławieństw". W ten sposób życie konsekrowane nieustannie przypomina Ludowi Bożemu o potrzebie odpowiadania świętością życia na miłość Bożą, rozlaną w sercach przez Ducha Świętego (por. Rz 5, 5), i wyrażania swoim postępowaniem sakramentalnej konsekracji, dokonanej przez Boga w chrzcie, bierzmowaniu lub w sakramencie święceńn ${ }^{28}$.

Uczestniczenie w tajemnicy Trójcy Świętej jest, w końcu, podstawową i ostateczną racją drogi doskonalenia się i świętości, przy akceptacji wysiłków i w stałej postawie nawrócenia w mocy Ducha Świętego ${ }^{29}$.

Światło trynitarne, które emanuje z tajemnicy przemienienia Chrystusa, wskazuje perspektywy tożsamości życia konsekrowanego i potwierdza, że - mimo wszystkich trudności egzystencjalnych, z jakimi mamy dzisiaj do czynienia - istnieje konkretna możliwość „,odnowionej ufności”30 , by podjąć ,pilne wyzwania” w odniesieniu do tej formy życia w Kościele. W tym celu powinno ono dokonać pogłębionego teologicznie rozumienia siebie jako przejścia „od Trójcy do Trójcy”. Taki mógłby być klucz do interpretacji tożsamości teologicznej życia konsekrowanego i do niego należałoby odwoływać się w interpretacji poszczególnych elementów oraz wydarzeń życia codziennego. Tajemnica Trójcy Świętej powinna stać się codziennym ,oddechem” osoby konsekrowanej i inspiracją do nieustannego poszukiwania konkretności Osób Boskich, które stanowi prawdziwy i właściwy ośrodek naszej wiary oraz wyrastającej z niej tożsamości chrześcijańskiej.

\section{Komunia braterska}

Już pierwsze rozdziały Dziejów Apostolskich, które zawsze odgrywały znaczącą rolę w teologicznej interpretacji życia zakonnego w Kościele, wskazują na szczególną świadomość i formę życia wspólnoty uczniów Chrystusa: ,Trwali oni w nauce Apostołów i we wspólnocie, w łamaniu chleba i w modlitwach” (Dz 2, 42); ,Jeden

\footnotetext{
VC 33.

Por. VC 35-39.

Por. VC 40.
} 
Duch i jedno serce ożywiały wszystkich wierzących. Żaden nie nazywał swoim tego, co posiadał, ale wszystko mieli wspólne” (Dz 4, 32). Kościół od samego początku miał silne poczucie „,braterstwa” i „komunii” jako elementów konstytutywnych swojego ,istnienia”. Były one także specyficznymi i wyróżniającymi znakami dostrzeganymi przez tych, którzy z uwagą patrzyli na życie uczniów Chrystusa, na ich postawy życiowe.

Mimo świadomości tej swojej specyfiki Kościół w swojej historii musiał zmierzyć się z rozmaitymi wyzwaniami, jakie stawały przed nim właśnie w odniesieniu do jego charakterystyki braterskiej i komunijnej. Być może największym wyzwaniem tego rodzaju były przemiany społeczne, kulturowe i religijne, jakie dokonywały się w średniowieczu, szczególnie dominujący wtedy wpływ feudalizmu stawiającego Kościołowi różne pytania, które dotykały samej istoty jego tożsamości. I właśnie wtedy niespodziewanie pojawił się człowiek, który swoim nawróceniem i swoją „,formą życia” podjął to wyzwanie - św. Franciszek z Asyżu. Marie-Dominique Chenu, wielki teolog francuski i znawca średniowiecza, tak zinterpretował pojawienie się Franciszka z jego przesłaniem ewangelicznym w ówczesnym świecie:

Jeśli inicjatywa św. Franciszka wywołała tak wielki wstrząs w chrześcijaństwie, że doprowadziła do stworzenia nowego wzoru jego struktury, to nie tylko dlatego, że zwracała się przeciw nadużyciom spowodowanym egoistycznym bogaceniem się, lecz przede wszystkim dlatego, że ponad barierami i przywilejami stworzonymi przez ustrój feudalny postawiła elementarne prawo braterstwa. Tak samo we wszystkich, żywych w owym czasie, ruchach biedoty nie chodziło bynajmniej o wywołanie powstania natury ekonomicznej, mającego na celu rewindykacje społeczne, ani o przekształcenie ewangelii w orędzie społeczne; braterstwo franciszkańskie bowiem przez samą swą czystość nadawało duchowe znaczenie i wymiar ewangeliczny ludzkiej dążności do wyzwolenia, budzącej się pod wpływem rozwoju rzemiosła i ożywionej wymiany handlowej ${ }^{31}$.

Nasze czasy stawiają wierzących wobec wyzwania analogicznego do tego średniowiecznego. Teraz jednak nie wynika on z wpływu

31 M.-D. Chenu, Wybór pism, tł. L. Rutowska, W. Sukiennicka, Z. Włodkowa, Warszawa 1971, s. 326. 
feudalizmu, choć i jego przejawy można jeszcze spotkać w wielu miejscach, ale z samotności człowieka współczesnego, który jeszcze raz prosi o nowe i konkretne odtworzenie mocy ewangelicznej słowa „bracia”. Człowiek dzisiejszy, z jednej strony, jest człowiekiem wpisanym w historię głęboko zunifikowaną na całym globie, jest człowiekiem wpisanym w globalną przestrzeń życiową, a więc mieszka w miejscu, w którym każdy jest powiązany w sposób uniwersalny z innymi, a także w pewien sposób jest uzależniony od wszystkich innych stworzeń. Ta globalizacja, jak pokazuje doświadczenie codzienne, nie wyzwala człowieka, ale go bezlitośnie przygniata, a w konsekwencji czuje się on samotny i zapomniany. A przecież czlowiek posiada podstawową potrzebę kogoś drugiego konkretnego, żywego i obecnego w sposób osobowy, chce odkryć się tam, gdzie inny konkretny człowiek robi mu miejsce nasycone obecnością; człowiek bardzo zwyczajnie i po prostu pragnie czuć się kochany przez drugiego człowieka. Dlatego tęskni za braterstwem, komunią, za konkretną obecnością kogoś drugiego. Ta sytuacja jest pilnym wyzwaniem dla całego Kościoła i dla każdego chrześcijanina. Świat potrzebuje nowego gestu („formy życia”) św. Franciszka - być może gestu jeszcze bardziej radykalnego, który będzie w stanie odpowiedzieć ewangelicznie na niespokojne oczekiwania dnia dzisiejszego i niezwykle szkodliwe alienacje osoby ludzkiej.

Rozdział drugi adhortacji Vita consecrata, który podejmuje zagadnienie życia konsekrowanego jako ,znaku komunii w Kościele” - ,,signum fraternitatis", jest organiczną kontynuacją rozdziału pierwszego i z niego wynika w sposób jak najbardziej bezpośredni. Trójca Święta jest komunią osób, udzielającą się w Kościele, który - ze swej strony - ,jest w swej istocie tajemnicą komunii, «ludem zgromadzonym przez jedność Ojca, Syna i Ducha Świętego»” ${ }^{2}$.

Komunia jest więc pierwotnym $\mathrm{i}$ istotnym wymiarem teologicznym życia chrześcijańskiego każdego wierzącego, a osoba konsekrowana powinna być „osobą komunii” w najwyższym stopniu. Właśnie to chce wskazać i uzasadnić adhortacja Vita consecrata:

Życie braterskie ma odzwierciedlać głębię i bogactwo tej tajemnicy, tworząc ludzką przestrzeń zamieszkałą przez Trójcę Przenajświętszą, która w ten sposób rozlewa w historii dary komunii, właściwe

32 VC 41. 
dla trzech Osób Boskich. W życiu Kościoła wiele jest dziedzin i form, w których wyraża się braterska komunia. Niewątpliwą zasługą życia konsekrowanego jest to, że właśnie dzięki niemu Kościół nadal żywo odczuwa potrzebę braterstwa jako wyznania wiary w Trójcę. Poprzez wytrwałe rozwijanie miłości braterskiej - w tym także we wspólnocie - ukazało ono, że uczestnictwo w trynitarnej komunii może przemienić ludzkie relacje i stworzyć nowy typ solidarności. W ten sposób ukazuje ono ludziom zarówno piękno braterskiej komunii, jak i konkretne drogi do niej. Osoby konsekrowane bowiem żyją „,dla” Boga i ,z” Boga i właśnie dlatego mogą świadczyć o mocy łaski, która przynosi pojednanie i niszczy mechanizmy przeciwne jedności, obecne w sercu czlowieka i w relacjach spolecznych ${ }^{33}$.

Rozdział drugi wskazuje następnie konkretne metody aktualizacji „komunii” wiary i życia oraz podaje jej podstawy teologiczne. Pierwszym i zasadniczym sposobem i równocześnie zadaniem tej aktualizacji jest ,życie braterskie w miłości”, słusznie widziane i rozważane w najszerszych wymiarach teologicznych:

W życiu wspólnotowym musi też w jakiś sposób wyrażać się fakt, że braterska komunia jest nie tylko narzędziem służącym określonej misji, ale przede wszystkim przestrzenią teologalną, w której można doświadczyć mistycznej obecności zmartwychwstałego Pana (por. Mt 18, 20). Dzieje się tak dzięki wzajemnej miłości członków wspólnoty, miłości karmionej słowem i Eucharystią, oczyszczanej w sakramencie pojednania, podtrzymywanej przez modlitwę o jedność - szczególny dar Ducha dla tych, którzy uważnie wsłuchują się w głos Ewangelii. To właśnie On, Duch Święty, wprowadza duszę w komunię z Ojcem i z Jego Synem Jezusem Chrystusem (por. 1 J 1, 3), komunię, która jest źródłem życia braterskiego. To Duch prowadzi wspólnoty życia konsekrowanego ku wypełnieniu ich misji w służbie Kościołowi i całej ludzkości, zgodnie z ich własną pierwotną inspiracją ${ }^{34}$.

Komunia nie ma więc charakteru ,,zewnętrznego”, ,funkcjonalnego” czy też „narzędziowego”, ale jest czymś pierwotnym i ontologicznym, przez co zakorzenia się w samej istocie konsekracji. Tylko 
wychodząc od takiego fundamentu rozumienia komunii można w pełni interpretować i przeżywać ,zadania władzy” 35 , dowartościowywać „,rolę osób starszych”36 oraz naśladować z oddaniem i w sposób konkretny życie wspólnoty apostolskiej ${ }^{37}$. Tylko w oparciu o podstawy teologiczne komunii, podejmując tradycyjną zasadę: ,sentire cum Ecclesia”, można podjąć pilne zadanie opracowywania „duchowości komunii” jako odpowiadającej na aktualne potrzeby zarówno osób konsekrowanych, jak i całego Kościoła:

Zmysł kościelnej komunii, rozwijając się w duchowość komunii, kształtuje sposób myślenia, mówienia i działania, który sprawia, że Kościól rozrasta się w głąb i wszerz. Życie w komunii staje się bowiem ,znakiem dla świata i przyciągającą siłą, która prowadzi do wiary w Chrystusa. [...] W ten sposób owa komunia otwiera się na dzieło misyjne, więcej, sama staje się misją"; można wręcz powiedzieć, że „,komunia rodzi komunię i w samej swej istocie przyjmuje kształt komunii misyjnej" 38 .

Duchowość komunii będzie z pewnością bardziej pomocna niż kodeksy normatywne w celu tworzenia relacji braterskich, tak w Kościele powszechnym, jak w Kościele partykularnym ${ }^{39}$, w dialogu z biskupami $^{40}$, przełożonymi ${ }^{41}, \mathrm{z}$ innymi instytutami ${ }^{42}$ i ze świeckimi ${ }^{43}$. W tej perspektywie będzie także możliwe odpowiednie dowartościowanie kobiety konsekrowanej ${ }^{44}$ oraz rozwinięcie nowych form jej obecności i działania.

Ta forma duchowości pozwoli zapewnić „,ciąłość w dziele Ducha Świętego" i ,wierność w nowości” różnych istniejących już form życia konsekrowanego, wprowadzić w życie Kościoła nowe formy życia ewangelicznego oraz widzieć w świetle ewangelicznym przyszłość

\footnotetext{
Por. VC 43.

Por. VC 44.

Por. VC 45.

VC 46.

Por. VC 47-48.

Por. VC 49.

Por. VC 50.

Por. VC 51-53.

Por. VC 54-56.

4 Por. VC 57.
} 
życia konsekrowanego, wytyczając równocześnie ukierunkowania i cele wielowymiarowej formacji osób konsekrowanych ${ }^{45}$. Uważam, że byłoby bardzo owocne dla życia konsekrowanego widzianego w jego całości nadanie nowego dynamizmu duszpasterstwu powołaniowemu, interpretując je właśnie w świetle teologii komunii. Aktualna praktyka jest jeszcze bardzo daleka od inspirowania się taką właśnie teologią. Często w ogóle brakuje odpowiednich podstaw i kryteriów teologicznych w tym typie duszpasterstwa, w wyniku czego zamienia się w jałową propagandę.

\section{Posłanie totalne}

W świetle Nowego Testamentu posłanie Jezusa Chrystusa, jak również posłanie tych wszystkich, którzy w Niego wierzą (nie tylko tych, którym zleca On szczególne zadanie), jest czymś więcej niż tylko faktem fundamentalnym. Sam Jezus wielokrotnie łączy te dwa posłania, akcentując ich ciągłość, mającą charakter tożsamości, a nie tylko prostego paralelizmu: ,Jak Ojciec Mnie posłał, tak i Ja was posyłam” (J 20,21). Tożsamość dotyczy nie tylko aktu posłania, ale także jego treści, którą Jezus otrzymał od Ojca: „Słowa bowiem, które Mi powierzyłeś, im przekazałem, a oni je przyjęli” (J 17, 8). Chodzi więc o przekazanie osobistego posłania Jezusa - Posłanego przez Ojca w Duchu Świętym. Możemy dodać, że chodzi o posłanie trynitarne Jezusa Chrystusa, które opiera się na Jego tożsamości trynitarnej.

To jest jeden z bardzo ważnych elementów teologii nowotestamentowej. Rzeczywista obecność Posyłającego w posyłanych - najpierw w apostołach, a potem w każdym uczniu, jest jedną z wielkich innowacji Nowego Testamentu oraz stanowi centrum tajemnicy Kościo$\mathrm{ła}^{46}$. Posłanie ucznia w życiu konsekrowanym ma chrystologiczno-trynitarne podstawy, w których odnajduje swoją specyfikę. Wszystko to jest bardzo istotne dla odpowiedniego zrozumienia, co oznacza „być konsekrowanym do pełnienia misji (posłania)”, jak mówi podtytuł wprowadzający do trzeciego rozdziału adhortacji Vita consecrata zatytułowanego ,Servitium caritatis. Życie konsekrowane objawieniem

45 Por. VC 59-71.

46 Por. H. Schürmann, Le groupe des disciples de Jésus, signe pour Israël et prototype de la vie selon les conseils, „Christus” 13 (1966), s. 184-209. 
Bożej miłości w świecie". Adhortacja tak łączy pojęcie posłania z teologią życia konsekrowanego:

Na podobieństwo Jezusa, umiłowanego Syna, ,którego Ojciec poświęcił i posłał na świat” (J 10, 36), również ci, których Bóg powołuje, aby szli za Nim, zostają poświęceni i posłani na świat, by naśladować Jego przykład i kontynuować Jego misję. Dotyczy to zasadniczo każdego ucznia, jednak w szczególny sposób odnosi się do tych, którzy są powołani, by w konkretnej formie życia konsekrowanego nasladować Chrystusa „,bardziej z bliska”, tak aby On był ,,wszystkim” w ich życiu. W ich wezwaniu jest zatem zawarte zadanie calkowitego poświęcenia się misji Chrystusa; więcej - pod działaniem Ducha Świętego, który jest źródłem każdego powołania i charyzmatu, samo życie konsekrowane staje się misją, tak jak było nią całe życie Jezusa. W tej perspektywie można również dostrzec, jak ważna jest profesja rad ewangelicznych, dzięki niej bowiem osoba staje się całkowicie wolna, aby poświęcić się sprawie Ewangelii. Należy zatem stwierdzić, że misja ma istotne znaczenie dla każdego instytutu, nie tylko dla Instytutów czynnego życia apostolskiego, ale także życia kontemplacyjnego ${ }^{47}$.

Do tych stwierdzeń o charakterze dogmatycznym, przede wszystkim, by móc „,całkowicie poświęcić się misji Chrystusa”, należy dodać także refleksję podkreślającą historyczność naszej rzeczywistości ludzkiej i osobistej. Jak posłanie Chrystusa miało jednoznacznie okreslony kontekst kulturowy i historyczny, nie spełniało się w abstrakcyjnej przestrzeni pozaświatowej, tak samo posłanie ucznia Chrystusa nie jest posłaniem ahistorycznym i abstrakcyjnym, ale posiada konkretny kontekst historyczny, który należy wziąć pod uwagę w aktualizacji jego posłania, tożsamego z posłaniem Chrystusa. Ta wrażliwość na historię nabiera dzisiaj szczególnego znaczenia w egzystencjalnym kontekście naszych posłań, który jest bardzo zmienny, zmienia się prawie z dnia na dzień. Nie ulega wątpliwości, że żyjemy w wyjątkowej chwili historycznej, ale w żadnym wypadku nie oznacza to, że nasze czasy są gorsze od innych, jak często pesymistycznie się uważa. Należy zauważyć, że prawie nigdy nie było czasów w pełni sprzyjających Kościołowi, a Kościół w czasach najbardziej niekorzystnych

47 VC 72. 
z ludzkiego punktu widzenia przeżywał nadzwyczajny rozkwit świętości i wzrost duchowy. Być może nie zdajemy sobie wystarczająco sprawy z tego, że Kościół nigdy w przeszłości nie miał takiego dynamizmu ewangeliczno-ludzkiego, jaki możemy obserwować właśnie dzisiaj. Zbyt często ulegamy wpływom ,,proroków nieszczęścia”48, którzy za wszelką cenę usiłują zawstydzić Kościół, aby wycofał się ze swojej misji w świecie.

Cały nasz problem antropologicznego ujęcia religii polega na wypracowaniu odpowiedniej metodologii podejmowania kwestii kontekstu historycznego. Myślę, że w świetle Ewangelii można by podać propozycję metodologiczną, która bierze pod uwagę trzy elementy: a) zwrócenie w pełni serca do Chrystusa; b) patrzenie na rzeczywistość realistycznie, by widzieć zarówno jej problemy (także obecne w niej zło), jak również jej dobrodziejstwa; c) ukierunkowanie najgłębszych pragnień ewangelicznych na przyszłość (papież św. Jan XXIII powiedział pewnego razu, że opłakiwanie ,,idealnej” przeszłości jest znakiem pogłębiającej się starości płaczącego). Chciałbym podkreślić w tym miejscu tylko trzeci element tej metodologii, który w pewnym sensie stoi u podstaw rozdziału trzeciego adhortacji Vita consecrata (dwa pierwsze elementy można odnaleźć w rozdziałach pierwszym i drugim). Tylko ten, kto umie patrzeć w przyszłość ewangelicznie, będzie umiał owocnie wypełniać swoje posłanie. Papież zachęcał: „Powinniście nie tylko wspominać i opowiadać swoją chwalebną przeszłość, ale także

48 Por. Benedykt XVI, Homilia podczas Mszy św. w święto Ofiarowania Pańskiego, (2 lutego 2013), „L'Osservatore Romano” 34 (2013) nr 3-4, s. 21: „Zachęcam was do odnowienia wiary, dzięki której jesteście pielgrzymami ku przyszłości. Życie konsekrowane ze swej natury jest pielgrzymką ducha w poszukiwaniu Oblicza, które niekiedy się objawia, a kiedy indziej skrywa: «Faciem tuam, Domine, requiram» (Ps 26, 8). Niech to będzie ustawicznym pragnieniem waszego serca, podstawowym kryterium, ukierunkowującym waszą drogę, zarówno w małych codziennych sprawach, jak i w najważniejszych decyzjach. Nie przyłączajcie się do proroków nieszczęścia, którzy głoszą kres lub bezsensowność życia konsekrowanego w Kościele naszych czasów; przyobleczcie się raczej w Jezusa Chrystusa i przywdziejcie zbroję światła - jak wzywa św. Paweł (por. Rz 13, 11-14) - bądźcie przebudzeni i czujni. Św. Chromacjusz z Akwilei pisał: "Oby Pan oddalił od nas niebezpieczeństwo dopuszczenia kiedykolwiek, byśmy stali się ociężali przez sen niewierności; a niech nam udzieli swej laski i swojego miłosierdzia, abyśmy mogli zawsze zachować czujność w wierności Jemu. W istocie, nasza wierność może czuwać w Chrystusie» (Sermone 32, 4)". 
budować nową wielką historię! W patrujcie się w przyszłość, ku której kieruje was Duch, aby znów dokonać z wami wielkich dzieł"49.

Chrześcijaństwo reprezentuje personalistyczne i egzystencjalne pojęcie czasu, które jest obce i nieznane rozmaitym utopiom przyszłościowym i wewnątrzświatowym - ograniczającym się tylko do świata doczesnego. Ten brak demaskuje ich niewystarczalność, ale także - należy dodać uczciwie - ten brak często staje się pokusą dla chrześcijan w ich interpretacji czasu i dziejów. W chrześcijańskim pojęciu czasu musi znaleźć się, jako istotne, pojęcie ,,przyszłości Bożej”, czyli wieczności, która już teraz ukazuje się w panowaniu Boga nad światem i dziejami. Ta przyszłość Boża została już zapoczątkowana, ale równocześnie musi zostać zdobyta przez ofiarę, często nawet bardzo bolesną. Człowiek ewangeliczny deklaruje wprost, że przyszłość osoby ludzkiej nie znajduje się wyłącznie w jakiejś bardziej lub mniej odległej przyszłości, ale że jest nią wieczność przeznaczona do ukazania się jako dar Boży, zbliżający się do świata właśnie w aktywności duchowej i osobowej człowieka ${ }^{50}$.

Jakie jest znaczenie tego wszystkiego w odniesieniu do postawionego wyżej zagadnienia posłania ucznia Chrystusa? W posłaniu ucznia Chrystusa są dwa podstawowe wymiary. Jeden wymiar jest oparty na gorliwej aspiracji, na podjęciu poszukiwania, na walce serca i ducha, by przeniknąć dzieje i to, co je przekracza. Można nazwać ten wymiar wymiarem ,męskim”. Drugi wymiar jest oparty na oczekiwaniu na otrzymanie daru oraz na byciu nim nasyconym i przenikniętym. Można nazwać go wymiarem przede wszystkim „kobiecym”. Ci, którzy są skoncentrowani na pierwszym wymiarze posłania, uświadamiają sobie każde ograniczenie i walczą z nim jako z przeszkodą do pokonania na drodze do przekroczenia siebie. Jeśli chodzi o różne ,wyzwania”, to przyjmująje oni jako pole wielowymiarowej walki ze względu na pełnię życia chrześcijańskiego, nawet jeśli nie zawsze zwracają uwagę na dobranie odpowiednich sposobów tej walki. Przedstawiciele drugiego wymiaru oczekują na to, co się w nich dokona, nie akcentując zbytnio ograniczeń, oraz są cierpliwi w prostych działaniach, wiedząc, że ich wartość i pełnia zależą przede wszystkim od łaski Bożej, która rzeczywiście nasyca człowieka i jego dzieła. Odkrywając wyzwania czasów, akceptują je spokojnie i otwarcie

49 VC 110.

50 Por. H. Weder, Tempo presente e signoria di Dio, Brescia 2005. 
jako dar Boży, wiedząc, że ma się w nich objawić moc i pełnia łaski Bożej, która przekształca wydarzenia historyczne i dzieła ludzkie oraz zdumiewająco napełnia je sensem wyższym ${ }^{51}$.

W naszych czasach jest obecny w dużym stopniu brak równowagi między tymi dwoma wymiarami posłania chrześcijańskiego. W dzisiejszej praktyce wymiar męski zbytnio wyprzedza wymiar kobiecy i zapomina się, że w perspektywie chrześcijańskiej pierwszeństwo - mimo wszystko - należy właśnie do wymiaru kobiecego. Każde stworzenie przyjmuje wobec Boga, który je nasyca, przede wszystkim postawę kobiecą; może ono dojść do swojej pełni tylko dzięki Bogu i Jego mocy. Przyjęcie pozycji męskiej wyraża się na końcu jako niespełnienie, niezadowolenie i nienasycenie, a w skrajnym przypadku może doprowadzić do zastąpienia boskiego Absolutu absolutem własnych idei - jakby dogmatyzacją swojego ja. Oczywiście, stworzenie nie jest tylko bierne w obliczu Boga, ale zbliża się do Niego w pewnej aktywności, aktywności zrównoważonej teologicznie i duchowo.

Adhortacja Vita consecrata proponuje osobom konsekrowanym posłanie, które opiera się mocno na tych zasadach i równowadze wymiarów posłania ewangelicznego. Pilne wyzwania aktualnej chwili historycznej i profetyczne spojrzenie w przyszłość prowadzą nas wszystkich na różne i bezgraniczne pola walki ewangelicznej i apostolatu: służba Bogu i czlowiekowi ${ }^{52}$; promocja kobiety ${ }^{53}$; ewangelizacja ${ }^{54}$; inkulturacja ${ }^{55}$; nowa ewangelizacja ${ }^{56}$; miłość ubogich i promocja sprawiedliwości ${ }^{57}$; troska o chorych ${ }^{58}$; wartości i rady ewangeliczne ${ }^{59}$; wychowanie $^{60}$; kultura ${ }^{61}$; środki społecznego przekazu ${ }^{62}$; dialog ekumeniczny i międzyreligijny ${ }^{63}$.

51 Por. H. U. von Balthasar, Duch chrześcijański, tł. Z. Włodkowa, Paris 1976, s. $75-82$.

52 Por. VC 73.

53 Por. VC $57-58$.

54 Por. VC 76-78

55 Por. VC 79-80.

56 Por. VC 81.

57 Por. VC 82.

58 Por. VC 83.

59 Por. VC 84-91.

60 Por. VC 96-97.

61 Por. VC 98.

62 Por. VC 100. 
Ta „męska walka” będzie jednak możliwa, jeśli absolutne pierwszeństwo zostanie dane temu, co kobiece, to znaczy wielowymiarowej otwartości teologiczno-duchowej na Boga, który przychodzi i działa jako Pierwszy, oczekując na przyjęcie. Takie powinno być pierwsze i pierwotne działanie osobowo-religijne każdego chrześcijanina. Dlatego właśnie adhortacja Vita consecrata w rozdziale trzecim kładzie tak bardzo silny nacisk na duchowość (oprócz wspomnianej już „duchowości komunii”): „rozwijać zdrową duchowość dzialania” ${ }^{64}$; „,milować sercem Chrystusa" ${ }^{65}$; przyjęcie ,jednoczącego działania Ducha Świętego" "66; , ,świadczyć, że Bóg jest prawdziwym bogactwem ludzkiego serca" ${ }^{7}$. Szczególnie mocne stwierdzenia na ten temat znajdujemy w numerze 93 . adhortacji:

Rodziny życia konsekrowanego muszą zatem stawiać na pierwszym miejscu życie duchowe, tak aby każdy instytut i każda wspólnota stanowila prawdziwą szkołę ewangelicznej duchowości. Od tej pierwszoplanowej opcji, realizowanej na plaszczyźnie osobistej i wspólnotowej, zależy apostolska owocność Instytutu, ofiarność jego miłości do ubogich, a także jego zdolność przyciagania powołań spośród nowych pokoleń. Właśnie wysoki poziom duchowy życia konsekrowanego może wstrząsnąc świadomością ludzi naszych czasów, którzy są spragnieni absolutnych wartości, i stać się w ten sposób porywającym świadectwem.

Tylko na bazie duchowości i jej jakości ewangelicznej, czyli na pierwszym działaniu życia konsekrowanego, będzie możliwa terapia życia konsekrowanego, i tylko w ten sposób życie konsekrowane będzie mogło wnieść wkład w „terapię duchową" ludzkości, na której potrzebę zwracał uwage papież Jan Paweł II, podejmując głosy ojców synodalnych ${ }^{68}$. Do tego samego pryncypium wielokrotnie powracał w swoim nauczaniu papież Benedykt XVI, nieustannie kładąc nacisk na prymat duchowości i milości w życiu chrześcijańskim. Akceptując te warunki ewangeliczne, życie konsekrowane będzie mogło stać się rzeczywiście profetyczną formą życia Kościoła - „szczególną formą uczestniczenia w prorockiej funkcji Chrystusa" ${ }^{69}$ - żywą silą przekształcania świata oraz przykładem

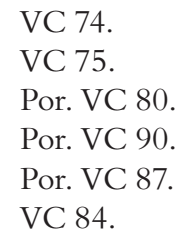


optymizmu ewangelicznego w realistycznym spojrzeniu na świat, który radykalnie zmienia swoją postać duchową, kulturową i obyczajową.

\section{Oczekiwany rozkwit życia konsekrowanego}

Zaczynając niniejsze refleksje, przytoczyłem myś wielkiego proroka czasów współczesnych, Pierre'a Teilharda de Chardin. Myślę, że również na zakończenie warto sięgnąć do jego przemyśleń, tym razem zaczerpniętych z listu pisanego 31 grudnia 1926 roku do Augusta Valensina:

Jakże chciałbym spotkać świętego Ignacego lub świętego Franciszka z Asyżu, których nasze czasy tak bardzo potrzebują. Iść za człowiekiem Bożym wolną i nową drogą, być przyciąganym pełnią żywotności religijnej jego czasu - jakiż sen! Proszę często Boga, abym był popiołem, w którym zakiełkuje dla innych wielki rozkwit, którego zabrakło naszemu pokoleniu! ${ }^{70}$.

Sądzę, że w adhortacji Vita consecrata św. Jana Pawła II jest zawarte takie samo pragnienie wielu nowych wielkich świętych zakonników i zakonnic, którzy mogliby zapoczątkować ,,wielki rozkwit” Ewangelii w świecie współczesnym i otworzyć do niej dostęp dla kolejnych pokoleń, które czekają na „ludzi Bożych”. I nie jest to „sen”, że przyjdą tacy ludzie, ale realistyczne, skierowane przez papieża do wszystkich osób konsekrowanych życzenie, które papież Franciszek w swoich wypowiedziach w trakcie Roku Życia Konsekrowanego wielokrotnie wyrażał, nadając mu odnowioną aktualność.

ks. Janusz Królikowski, Życie zakonne między konsekracją, komunia i postaniem, [w:] Życie konsekrowane znakiem wiarygodności Kościoła, red. ks. Andrzej Dudek, ks. Robert Kantor, Kraków 2016, s. 14-34 (Lumen Gentium, 2).

DOI: http://dx.doi.org/10.15633/9788374385725.04

70 Lettres - Lettres intimes de Teilhard de Chardin à Auguste Valensin, Bruno de Solages, Henri de Lubac, André Ravier (1919-1955), éd. H. de Lubac, éd. 2, Paris 1974, s. 143. 